\title{
SCARUS CROICENSIS.
}

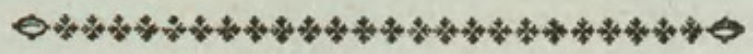

CHARACTER GENERICUS.

Caput: Dentium loco maxillæ ipsæ eminentes; margine dentato-crenatæ osseæ.

Membrana lranchiostega radiisquinque; Operculum integerrimum.

Corpus: Linea lateralis plurimis ramosa.

Lin. Syst. Nat. Gmel. p. 1280.

Character SPECIFICUS, Eंc.

SCARUS pinna caudæ rotundata.

Bloch. ichth. 7. p. 18. t. 221. Pisc. Thoracici.

Maria Indica et Americana incolit Scarus Croicensis, a Blochio primum depictus. Coloribus variat; interdum totus ruber, interdum fasciis argenteo-albis insignitus. In pedalem crescit longitudinem. 




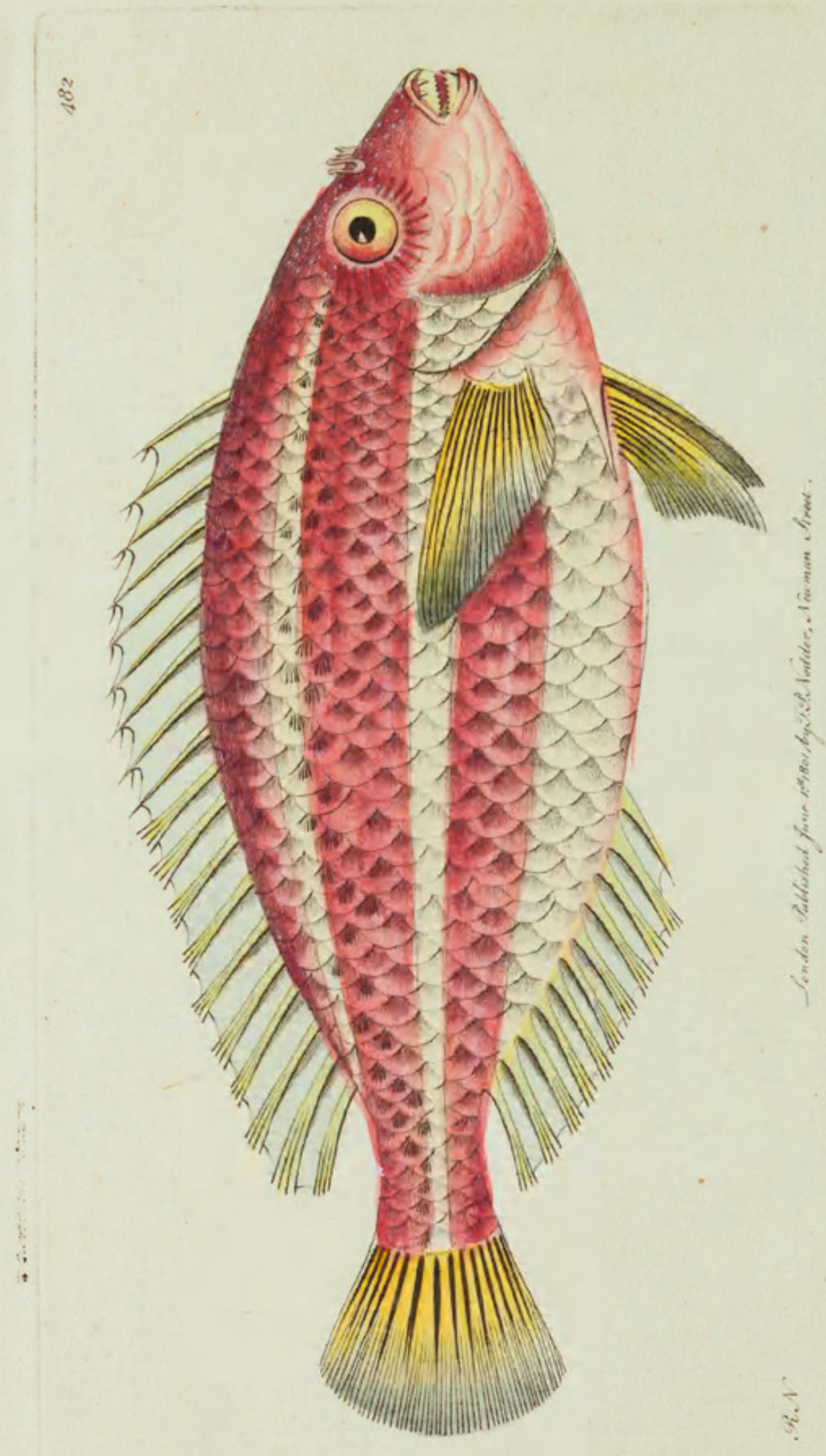




\section{THE \\ RED SCARUS.}

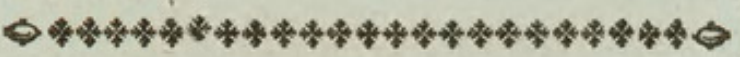

GENERIC CHARACTER.

Strong bony processes, crenated at the edges, instead of teeth.

SPECIFIC CHARACTER, $\Xi^{2}$.

RED SCARUS, with rounded tail, and the body sometimes marked by silvery-white stripes.

Der rothe Papagey-Fisch.

Bloch. ichth. pl. 221.

This elegant species, measuring about twelve inches in length, is a native of the Indian and American seas and was first figured in the work of Dr. Bloch. In color it varies; being sometimes entirely red, and sometimes marked with longitudinal silvery-white stripes. 


\section{$2 \mathrm{BHL}$ Biodiversity Heritage Library}

Shaw, George. 1800. "The Red Scarus, Scarus croicensis [PI. 482]." The Naturalist's Miscellany 12(CXXXV), https://doi.org/10.5962/p.310928.

View This Item Online: https://www.biodiversitylibrary.org/item/278722

DOI: https://doi.org/10.5962/p.310928

Permalink: https://www.biodiversitylibrary.org/partpdf/310928

\section{Holding Institution}

Museums Victoria

\section{Sponsored by}

Atlas of Living Australia

\section{Copyright \& Reuse}

Copyright Status: Public domain. The BHL considers that this work is no longer under copyright protection.

This document was created from content at the Biodiversity Heritage Library, the world's largest open access digital library for biodiversity literature and archives. Visit BHL at https://www.biodiversitylibrary.org. 